\title{
PENGARUH BUDAYA ORGANISASI DAN DISIPLIN KERJA TERHADAP PRODUKTIVITAS KERJA KARYAWAN PADA PT BANK MESTIKA DHARMA, TBK. CABANG PEMATANGSIANTAR
}

\author{
Oleh: \\ Juli Enggana \\ S1 Manajemen \\ Darwin Lie, Efendi, Julyanthry
}

\begin{abstract}
Abstraksi
Penelitian ini dilakukan dengan menggunakan teknik analisis deskriptif kuantitatif dan deskriptif kualitatif. Adapun populasi penelitian ini adalah karyawan PT Bank Mesika Dharma, Tbk. Cabang Pematangsiantar sebanyak 40 orang. Pengumpulan data dilakukan dengan kuesioner, wawancara, observasi dan dokumentasi. Teknik analisis yang digunakan ialah regresi linear berganda, koefisien korelasi dan determinasi, dan pengujian hipotesis dengan Uji F dan Uji t.

Hasil penelitian dapat disimpulkan sebagai berikut: 1. Karyawan telah menerapkan budaya organisasi dengan kuat, disiplin kerja yang dilaksanakan baik dan produktivitas kerja karyawan baik. 2 . Hasil pengujian regresi linear berganda adalah $\hat{Y}=5,819+0,689 X_{1}+0,192 X_{2}$, artinya budaya organisasi dan disiplin kerja berpengaruh positif terhadap produktivitas kerja karyawan PT Bank Mesika Dharma, Tbk. Cabang Pematangsiantar. 3. Hasil analisis korelasi nilai $r=0,844$ artinya terdapat hubungan yang sangat kuat dan positif antara budaya organisasi dan disiplin kerja dengan produktivitas kerja karyawan PT Bank Mestika Dharma, Tbk. Cabang Pematangsiantar. Kemudian nilai koefisien determinasi $(\mathrm{KD})$ yaitu 0,713 , yang artinya tinggi rendahnya produktivitas karyawan dapat dijelaskan sebesar $71,3 \%$ oleh budaya organisasi dan disiplin kerja. 4. Hipotesis $\mathrm{H}_{0}$ ditolak, artinya budaya organisasi dan disiplin kerja berpengaruh positif dan signifikan terhadap produktivitas kerja karyawan PT Bank Mestika Dharma, Tbk. Cabang Pematangsiantar baik secara simultan maupun parsial.

Adapun saran dari penelitian ini adalah untuk variabel budaya organisasi, hendaknya lebih memperhatikan penerapan budaya organisasi agar tujuan perusahaan dapat tercapai. Selanjutnya, variabel disiplin kerja perlu memberikan arahan kepada seluruh karyawan serta memberikan sanksi kepada karyawan yang tidak disiplin. Sedangkan variabel produktivitas kerja karyawan diharapkan agar atasan mendorong karyawannya untuk melakukan upaya-upaya yang maksimal dalam melakukan pekerjaannya untuk mencapai tujuan perusahaan.
\end{abstract}

Kata Kunci: Budaya Organisasi, Disiplin Kerja dan Produktivitas Kerja

Abstraction

This research is done by using quantitative and qualitative descriptive. The population in this research are 40 employees at PT Bank Mestika Dharma, Tbk. Branch Pematangsiantar. File was collected by using questionnaires, interviews, observation and documentation. File analysis technic is using multiple linear regression, coefficient of correlation and determination, and hypothesis test.

The result of this research showed us: 1. Employee have implemented organizational culture strongly, work discipline is good and productivity of employee is good. 2. The results of regression testing is $\hat{Y}=5,819+0,689 X_{1}+0,192 X_{2}$ means this research have a positive influence between of the organizational culture and work discipline to the productivity of employee. 3. correlation analysis and value $r=0,844$ it means there are a very strong and positive relationship between organizational culture and work discipline to the productivity of employee, then the value of the coefficient of determination (KD) 0,713. The level of productivity of employee can be explained by the organizational culture and work discipline by $71,3 \%$. 4. Hypothesis $H_{0}$ is rejected, meaning that the organizational culture and work discipline has positive and significantly influence to the productivity of employee at $P T$ Bank Mestika Dharma, Tbk. Branch Pematangsiantar either simultaneously or partially.

There are some suggestion from this research for organizational culture variable must be pointed on implementation culture organization so the main intention of the company can be reach. Next, the variable of work discipline that need to give some direction to all staff and give them some punishment to the staff who undisciplined. Beside that for the variable productivity of employee to be expect for the superior can give some encouragement to give the maximal effort with the work activity for reach the goal objective of the company.

Keywords: Organizational Culture, Work Discipline and Productivity of employee
A. PENDAHULUAN
1. Latar Belakang Masalah 
PT Bank Mestika Dharma, Tbk. Cabang Pematangsiantar merupakan salah satu perbankan swasta yang berskala nasional yang berada di provinsi Sumatera Utara. PT Bank Mestika Dharma, Tbk. Cabang Pematangsiantar dalam aktivitas kerjanya berusaha untuk selalu menekankan kepada seluruh sumber daya manusianya untuk dapat mencapai produktivitas kerja yang baik.

Adapun fenomena produktivitas kerja karyawan PT Bank Mestika Dharma, Tbk. Cabang Pematangsiantar adalah diukur berdasarkan sebagai berikut:

Tabel 1

Fenomena Produktivitas Kerja Karyawan

\begin{tabular}{|c|c|c|c|c|c|c|}
\hline Dlmenes & कB & B & $\mathrm{CB}$ & TB & STE & Jymah \\
\hline xhatyas & $20 \mathrm{~W}$ & $30 \%$ & $11 \%$ & 35 & & $160 \%$ \\
\hline Kuvíjplinse & $15 \%$ & $27 \%$ & $52 \%$ & 88 & & $100 \%$ \\
\hline$\frac{\text { Elps Keria }}{\text { Kelerampalan }}$ & $\frac{138}{184}$ & $\frac{20 \%}{28 \pi}$ & $\frac{513 i}{182}$ & $\frac{3 k}{1,2 k}$ & & $\frac{100 \%}{100 \%}$ \\
\hline  & $18 \%$ & $\mid 27 \%$ & $50 \%$ & $5 \%$ & - & $100 \%$ \\
\hline
\end{tabular}

Sumber: hasil wawancara dengan HRD PT Bank Mestika Dharma, Tbk. Cabang Pematangsiantar.

Berdasarkan, dapat dilihat bahwa produktivitas kerja yang paling rendah yaitu pada dimensi etos kerja, yaitu tingkat ketelitian dalam bekerja. Masih banyaknya temuan audit dan temuan accounting akibat ketidaktelitian karyawan dalam bekerja, serta banyaknya koreksi yang dilakukan akibat salah penginputan oleh karyawan. Pada dimensi kedisiplinan, yaitu tingkat kehadiran karyawan, adanya beberapa karyawan yang tidak hadir akibat sakit ringan yang sebenarnya masih bisa diatasi. Secara umum, produktivitas masih belum optimal dan perlu ditingkatkan lagi.

Salah satu faktor yang mempengaruhi produktivitas kerja karyawan yaitu budaya organisasi. Dimensi budaya organisasi pada PT Bank Mestika Dharma, Tbk. Cabang Pematangsiantar antara lain komitmen, kompetensi, kerjasama, keterbukaan dan kejujuran. PT Bank Mestika Dharma, Tbk. Cabang Pematangsiantar berkomitmen yang kuat untuk tetap sebagai anggota organisasi, dan bekerja keras untuk perusahaan demi tercapainya tujuan perusahaan. Karyawan PT Bank Mestika Dharma, Tbk Cabang Pematangsiantar selalu memanfaatkan sumber daya dalam meningkatkan pengetahuan. Karyawan juga diberikan pelatihan dan pengembangan guna untuk meningkatkan kompetensi sesuai bidang dan tugasnya. PT Bank Mestika Dharma, Tbk. Cabang Pematangsiantar membangun kerjasama yang solid di dalam tim, baik dalam hal komunikasi, saling berbagi informasi, dan saling membantu antar karyawan sehingga tercipta hubungan yang harmonis.

Disiplin kerja juga merupakan faktor yang mempengaruhi produktivitas kerja karyawan. Dimensi disiplin kerja pada PT Bank Mestika Dharma, Tbk. Cabang Pematangsiantar antara lain tingkat kehadiran, ketaatan pada Standart Operation Procedure, ketaatan pada kode etik, pelaksanaan Good Corporate Governance. Tingkat kehadiran dinilai berdasarkan jumlah absensi, ketepatan waktu datang bekerja, dan disiplin mengikuti kegiatan kantor. Karyawan PT Bank Mestika Dharma, Tbk. Cabang Pematangsiantar wajib menaati semua standar kerja yang telah ditetapkan sesuai dengan aturan dan pedoman kerja agar kecelakaan kerja tidak terjadi atau dapat dihindari.

\section{Rumusan Masalah}

a. Bagaimana gambaran budaya organisasi, disiplin kerja dan produktivitas kerja karyawan pada PT Bank Mestika Dharma, Tbk. Cabang Pematangsiantar.

b. Bagaimana pengaruh budaya organisasi dan disiplin kerja terhadap produktivitas kerja karyawan pada PT Bank Mestika Dharma, Tbk. Cabang Pematangsiantar baik secara simultan maupun parsial.

\section{Tujuan Penelitian}

a. Untuk mengetahui gambaran budaya organisasi, disiplin kerja dan produktivitas kerja karyawan pada PT Bank Mestika Dharma, Tbk Cabang Pematangsiantar.

b. Untuk mengetahui pengaruh budaya organisasi dan disiplin kerja terhadap produktivitas kerja karyawan pada PT Bank Mestika Dharma, Tbk. Cabang Pematangsiantar baik secara simultan maupun parsial.

\section{Metode Penelitian}

Objek penelitian adalah PT Bank Mestika Dharma, Tbk. Cabang Pematangsiantar yang terletak di Jalan Merdeka No. 231-233 Pematangsiantar. seluruh karyawan pada PT Bank Mestika Dharma, Tbk. Cabang Pematangsiantar yang berjumlah 40 orang. Seluruh karyawan yang berjumlah 40 orang akan menjadi responden untuk menjawab kuesioner yang disebarkan.

Desain penelitian adalah Penelitian Kepustakaan (Library Research) dan Penelitian Lapangan (Field Research). Teknik pengumpulan data berupa Kuesioner, Wawancara dan Dokumentasi. Jenis data yang adalah jenis data kualitatif dan data kuantitatif. Hasil data yang diperoleh dari lapangan akan dianalisis secara deskriptif baik bersifat kualitatif dan kuantitatif.

\section{B. LANDASAN TEORI}

1. Manajemen Sumber Daya Manusia

Menurut Dessler (2004:5), manajemen sumber daya manusia adalah proses memperoleh, melatih, menilai, dan memberikan kompensasi kepada karyawan, memerhatikan hubungan kerja mereka, kesehatan, keamanan, dan masalah keadilan. Sedangkan menurut 
Mathis dan John (2006:3), manajemen sumber daya manusia adalah rancangan sistem-sistem formal dalam sebuah organisasi untuk memastikan penggunaan bakat manusia secara efektif dan efisien guna mencapai tujuan-tujuan organisasi. Dari uraian di atas, penulis menyimpulkan bahwa manajemen sumber daya manusia merupakan serangkaian sistem yang dibutuhkan untuk mengatur hubungan tenaga kerja dalam menjalankan fungsi manajemen guna mencapai tujuan organisasi.

\section{Budaya Organisasi}

Menurut Sutrisno (2010:2), budaya organisasi adalah sebagai perangkat sistem nilai-nilai (values), keyakinan-keyakinan (beliefs), asumsi-asumsi (assumptions), atau norma yang telah lama berlaku, disepakati dan diikuti oleh para anggota suatu organisasi sebagai pedoman perilaku dan pemecahan masalah-masalah organisasinya. Menurut Robbins dan Timothy (2008:256), budaya organisasi merupakan sebuah sistem bersama yang dianut para anggota yang membedakan suatu organisasi dengan organisasi lainnya. Dari pendapat para ahli di atas, dapat disimpulkan bahwa budaya organisasi adalah nilai-nilai atau panutan organisasi yang menjadi pembeda antara satu organisasi dengan organisasi lain yang menjadi ciri khas suatu organisasi yang nantinya sangat berguna untuk mencapai tujuan organisasi tersebut.

Adapun karakteristik budaya organisasi menurut Bank Mestika Dharma, Tbk. (2015), yaitu:

komitmen, kompetensi, kerjasama, keterbukaan, dan kejujuran

\section{Disiplin Kerja}

Menurut Sinungan (2009:135), disiplin adalah sikap kejiwaan dari seseorang atau sekelompok orang yang senantiasa berkehendak untuk mengikuti atau mematuhi segala aturan atau keputusan yang telah di tetapkan. Menurut Sutrisno (2009:87), disiplin diartikan sebagai suatu kekuatan yang berkembang di dalam tubuh karyawan dan menyebabkan karyawan dapat menyesuaikan diri dengan sukarela pada keputusan, peraturan, dan nilai-nilai tinggi dari pekerjaan dan perilaku. Berdasarkan pendapat ahli di atas, dapat disimpulkan bahwa disiplin adalah kesadaran seseorang dalam menjalankan prosedur dan mematuhi segala peraturan atau keputusan yang telah ditetapkan.

Adapun faktor yang mempengaruhi disiplin kerja menurut Surat Keputusan Bank Mestika SK. No.19/SK-BMD/DIR/2015, yaitu: tingkat kehadiran,

ketaatan pada Standar Operation Prosedure, ketaatan pada kode etik, dan pelaksanaan Good Corporate Governance.

\section{Produktivitas Kerja}

Menurut Sirait (2006:46), produktivitas kerja adalah kemampuan seperangkat sumbersumber ekonomi untuk menghasilkan sesuatu atau perbandingan antara pengorbanan dengan penghasilan. Sedangkan menurut Bestari (2004:16), produktivitas kerja adalah perbandingan antara jumlah barang dan jasa yang dihasilkan (output) dengan jumlah sumber daya yang dipakai (input). Berdasarkan pengertian diatas, dapat disimpulkan bahwa produktivitas kerja adalah kemampuan untuk melakukan kegiatan yang menghasilkan hasil kerja sesuai dengan mutu yang ditetapkan dalam waktu yang lebih singkat dari seorang tenaga kerja.

Menurut Sedarmayanti, (2011:214), faktor yang mempengaruhi tinggi rendahnya produktivitas kerja, yaitu: motivasi, kedisiplinan, etos kerja, keterampilan, dan pendidikan.

\section{PEMBAHASAN \\ 1. Analisa}

\section{a. Deskriptif Kualitatif}

Analisa deskriptif kuantitatif dimaksudkan untuk mendapatkan gambaran atau deskripsi mengenai tanggapan dari karyawan mengenai Pengaruh Budaya Organisasi dan Disiplin Kerja Terhadap Produkivitas Kerja Karyawan PT Bank Mestika Dharma, Tbk. Cabang Pematangsiantar. Sesudah pegujian data maka langkah selanjutnya penelitian melakukan pengkajian analisis kualitatif sebagai gambaran fenomenal dari variabel penelitian pada saat sekarang ini. Adapun penetapan kriteria nilai rata-rata jawaban dari responden tersebut dimasukkan ke dalam kelas-kelas interval dimana penentuan intervalnya memakai rumus sebagai berikut:

Interval Kelas $=$ Nilai Tertinggi - Nilai Terendah

$$
\begin{aligned}
& =\frac{5-1}{5} \\
& =\frac{4}{5} \\
& =0,8
\end{aligned}
$$
Jumlah Kelas

Dari rumus diatas dapat diperoleh interval kelas 0,8 sehingga berlaku ketentuan kategori dengan hasil berikut:

Tabel 2

\begin{tabular}{|c|c|c|c|}
\hline \multirow{2}{*}{$\underset{\text { Interval }}{\text { Mlal }}$} & \multicolumn{3}{|c|}{ Kulkgyui } \\
\hline & Ther: ayn Corgman anal & Thalp & $\begin{array}{l}\text { Pendinkrilens } \\
\text { Karla }\end{array}$ \\
\hline $1.60-1.80$ & उaา: & 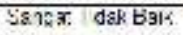 & 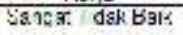 \\
\hline $181 \quad 260$ & Ler ost & Tiz:s Buik. & Tisat 5ial. \\
\hline $2,61 \quad 3, \Delta 6$ & Cut.I: Ku... & $\alpha$ sup Bsi: & $\alpha$ sup Buis \\
\hline $3.11-120$ & Kıal & Bals & Salk \\
\hline दि $5 \mathrm{~m}$ & Sargat kut & Borgatlas & Sormatis? \\
\hline
\end{tabular}

Nilai Interval dan Kategori Jawaban Responden.

Sumber : hasil pengolahan data 


\section{1) Gambaran Budaya Organisasi Pada PT Bank Mestika Dharma, Tbk. Cabang Pematangsiantar}

Dari hasil analisa, untuk dimensi komitmen pada PT Bank Mestika Dharma, Tbk. Cabang Pematangsiantar berdasarkan indikator kesesuaian kewajiban yang dijalankan memperoleh nilai rata-rata 3,98 dengan kriteria jawaban kuat, dikarenakan karyawan bekerja dengan sungguh-sungguh dan sesuai kewajibannya masing-masing. Pada indikator kesetiaan terhadap perusahaan memperoleh nilai rata-rata 4,08 dengan kriteria jawaban kuat, dikarenakan karyawan yang telah lama bekerja akan nyaman dalam bekerja dan loyal terhadap perusahaan. Pada indikator yang terakhir yaitu keinginan dalam mewujudkan tujuan perusahaan memperoleh nilai rata-rata 3,13 dengan kriteria jawaban cukup kuat, hal in disebabkan karena masih adanya karyawan yang bekerja tidak sepenuh hati dan kurang maksimal sehingga rendahnya keinginan karyawan dalam mewujudkan tujuan perusahaan

Selanjutnya untuk dimensi kompetensi pada indikator pemanfaatan sumber daya dalam meningkatkan pengetahuan memperoleh nilai rata-rata sebesar 3,90 dengan kriteria jawaban kuat, hal dikarenakan pimpinan selalu memberikan informasi terbaru perbankan guna meningkatkan pengetahuan karyawan. Selanjutnya pada indikator sikap dalam memecahkan permasalahan dengan nilai ratarata 3,85 dengan kriteria jawaban kuat, dikarenakan karyawan memiliki ide-ide yang inovatif dan dapat berinisiatif dalam menyelesaikan masalah. Pada indikator tanggung jawab terhadap pekerjaan berada pada rata-rata 3,75 dengan kriteria jawaban kuat, hal ini dikarenakan karyawan mengerti dan memahami pekerjaan yang diberikan serta menyelesaikannya tepat waktu.

Pada dimensi kerjasama untuk indikator komunikasi dengan atasan memperoleh ratarata 4,00 dengan kriteria jawaban kuat, hal in disebabkan karyawan dan atasan selalu berkomunikasi dan bertukar pikiran dalam bekerja. Pada indikator kerjasama yang solid dalam tim memperoleh rata-rata 4,30 dengan kriteria jawaban sangat kuat, hal ini disebabkan karena karyawan saling berkerjasama, saling membantu dan saling bertukar pikiran dalam menyelesaikan pekerjaan. Pada indikator hubungan saling membantu antar karyawan pada PT Bank Mestika Dharma, Tbk. Cabang Pematangsiantar memperoleh nilai rata-rata 4,05 dengan kriteria jawaban baik, hal ini dikarenakan karyawan saling membantu satu sama lain dalam memecahkan permasalahan maupun menyelesaikan pekerjaan.

Pada dimensi keterbukaan pada indikator kepercayaan antar karyawan memperoleh ratarata 3,63 dengan kriteria jawaban kuat, disebabkan karena karyawan saling jujur dan bertukar informasi dalam bekerja. Pada indikator hubungan antar karyawan memperoleh rata-rata 3,75 dengan kriteria jawaban kuat, dikarenakan karyawan saling membantu dan menciptakan hubungan yang harmonis dalam bekerja. Pada indikator yang terakhir yaitu keterbukaan informasi dengan karyawan lain memperoleh nilai 3,73 dengan kriteria jawaban kuat, disebabkan karena karyawan saling terbuka dalam menyampaikan informasi, memberikan ide, strategi, gagasan dan inovasi baru.

Dimensi yang terakhir yaitu kejujuran pada indikator kerelevan informasi memperoleh rata-rata 3,70 dengan kriteria kuat, dikarenakan informasi yang diberikan karyawan nyata dan dapat dibuktikan kebenarannya. Indikator semangat dalam bekerja dengan rata-rata 3,85 dengan kriteria kuat, dikarenakan lingkungan kerja yang nyaman dan rekan kerja yang saling mendukung satu sama lain sehingga karyawan semangat dalam bekerja. Indikator yang terakhir yaitu kejujuran sesama karyawan dengan rata-rata 3,75 dengan kriteria kuat, disebabkan karena karyawan saling jujur, saling menghormati dan saling percaya dalam bekerja maupun dalam memberikan informasi.

Dari total jawaban responden mengenai budaya organisasi dari segi komitmen, kompetensi, kerjasama, keterbukaan dan keujujuran mendapat nilai rata-rata sebesar 3,83 dengan kriteria jawaban kuat. Kemudian nilai rata-rata tertinggi sebesar 4,30 dengan kriteria jawaban sangat kuat untuk dimensi kerjasama pada indikator kerjasama yang solid di dalam tim. Sedangkan nilai rata-rata terendah sebesar 3,13 untuk dimensi komitmen pada indikator keinginan dalam mewujudkan tujuan perusahaan.

\section{2) Gambaran Disiplin Kerja Pada PT Bank Mestika Dharma, Tbk. Cabang \\ Pematangsiantar}

Dari hasil analisa, untuk dimensi tingkat kehadiran pada indikator tingkat kehadiran di tempat kerja dengan rata-rata 3,80 dengan kriteria jawaban baik, hal ini dikarenakan karyawan hadir setiap hari dan sedikitnya jumlah absensi ketidakhadiran. Pada indikator ketepatan waktu datang bekerja, responden memberi nilai rata-rata 3,40 dengan kriteria jawaban cukup baik, hal ini terjadi karena banyaknya absensi keterlambatan karyawan. Sedangkan pada indikator disiplin mengikuti kegiatan kantor dengan nilai rata-rata yaitu 4,10 dengan kriteria jawaban baik, hal ini disebabkan karena karyawan selalu mengikuti kegiatan kantor seperti rapat, sosialisasi dan acara kantor lainnya.

Selanjutnya pada dimensi ketaatan pada Standart Operation Procedure pada indikator kerapian dalam berpakaian memperoleh nilai 
rata-rata 4,05 dengan kriteria jawaban baik, dikarenakan karyawan selalu berpakaian dan berpenampilan yang rapi dan lengkap. Pada indikator kebersihan lingkungan kerja dengan rata-rata 3,75 dengan kriteria baik, hal in dikarenakan karyawan selalu memperhatikan lingkungan kerja serta adanya petugas kebersihan yang selalu menjaga kebersihan tempat kerja. Selanjutnya pada indikator efisiensi penggunaan fasilitas kantor memperoleh nilai rata-rata 3,60 dengan kriteria jawaban baik, hal ini dikarenakan karyawan selalu menghemat penggunaan fasilitas kantor seperti kertas, pulpen, dan lain sebagainya, serta memanfaatkan barang yang masih berguna.

Pada indikator ketaatan terhadap peraturan memperoleh rata-rata 3,70 dengan kriteria jawaban baik, disebabkan karena seluruh karyawan wajib mematuhi segala bentuk Undang-Undang, hukum, peraturan dan ketentuan lainnya yang telah ditetapkan. Indikator yang terakhir yaitu kesesuaian SOP dalam bekerja memperoleh nilai rata-rata 3,98 dengan kriteria baik, hal ini disebabkan karena karyawan wajib menjalankan prosedur perusahaan yang telah ditetapkan sesuai jabatannya masing-masing.

Pada dimensi ketaatan pada kode etik untuk indikator menjaga kerahasiaan bank memperoleh nilai rata-rata 3,93 dengan kriteria jawaban baik, hal ini dikarenakan karyawan wajib menjaga rahasia bank seperti data dan informasi bank yang bersifat rahasia. Selanjutnya pada indikator menjaga kerahasiaan nasabah memperoleh nilai ratarata 4,05 dengan kriteria jawaban baik, hal ini disebabkan karena karyawan wajib melindungi data dan informasi nasabah yang bersifat rahasia. Selanjutnya indikator keadilan pelayanan yang diberikan kepada nasabah memperoleh nilai rata-rata 3,90 dikarenakan karyawan dilarang mengambil keuntungan secara tidak adil dari nasabah melalui manipulasi, penyelewengan, penyalahgunaan informasi yang bersifat rahasia. Pada indikator yang terakhir yaitu perlindungan terhadap asetaset bank memperoleh nilai rata-rata 4,15 dengan kriteria jawaban baik, hal ini disebabkan karena karyawan wajib melindungi aset berwujud dan tidak berwujud seperti uang tunai, surat-surat berharga, property fisik, peralatan bank, dan seluruh informasi rahasia bank.

Pada dimensi yang terakhir yaitu pelaksanaan Good Corporate Governance untuk indikator kesesuaian tanggung jawab dengan nilai rata-rata 4,05 dengan kriteria jawaban baik, hal ini disebabkan karena karyawan bekerja sesuai tanggungjawabnya masing-masing dan tidak mengesampingkan pekerjaannya. Pada indikator tingkat kehatihatian dalam bekerja dengan nilai rata-rata sebesar 3,90 dengan kriteria jawaban baik, hal ini disebabkan karena karyawan bekerja dengan teliti dan hati-hati sehingga meminimalkan kesalahan yang dapat terjadi. Selanjutnya pada indikator tingkat kepuasan hasil kerja dengan nilai 4,15 dengan kriteria jawaban baik, hal ini disebabkan karena karyawan bekerja dengan maksimal dan berusaha untuk mencapai hasil terbaik.

Dari total jawaban responden mengenai budaya organisasi baik dari segi tingkat kehadiran, ketaatan pada Standart Operation Procedure, ketaatan pada kode etik, dan pelaksanaan Good Corporate Governance mendapat nilai rata-rata sebesar 3,90 dengan kriteria jawaban baik. Nilai rata-rata tertinggi sebesar 4,15 dengan kriteria jawaban baik untuk dimensi ketaatan pada kode etik pada indikator perlindungan aset-aset bank dan pada dimensi pelaksanaan Good Corporate Governance pada indikator tingkat kepuasan hasil kerja. Sedangkan nilai rata-rata terendah sebesar 3,40 dengan kriteria jawaban cukup baik untuk dimensi tingkat kehadiran pada indikator ketepatan waktu datang bekerja.

\section{3) Gambaran Produktivitas Kerja Karyawan Pada PT Bank Mestika Dharma, Tbk. Cabang Pematangsiantar}

Dari hasil analisa, untuk dimensi motivasi pada indikator pengarahan yang diberikan atasan mendapat nilai rata-rata 4,00 dengan kriteria baik, hal ini disebabkan karena atasan selalu memberikan masukan serta arahan dalam menyelesaikan pekerjaan. Selanjutnya pada indikator pemahaman atasan terhadap kemampuan memperoleh nilai rata-rata sebesar 4,10 dengan kriteria baik, hal ini dikarenakan atasan paham akan kemampuan karyawan melalui penilaian prestasi karyawan. Pada indikator yang terakhir yaitu dukungan yang diberikan atasan memperoleh nilai rata-rata sebesar 3,63 dengan jawaban baik, hal ini dikarenakan atasan selalu menyemangati karyawan dengan memberikan dukungan serta arahan yang memacu karyawan semangat dalam bekerja.

Selanjutnya untuk dimensi kedisiplinan pada indikator ketepatan waktu menyelesaikan pekerjaan memperoleh nilai rata-rata sebesar 3,75 dengan kriteria baik, hal ini disebabkan karena karyawan bekerja dengan cepat dan selesai dengan tepat waktu. Pada indikator tingkat kehadiran karyawan memperoleh nilai rata-rata sebesar 3,73 dengan kriteria jawaban baik, hal ini disebabkan karena karyawan selalu hadir dan sedikitnya jumlah absensi ketidakhadiran. Pada indikator yang terakhir yaitu ketaatan terhadap prosedur kerja dengan nilai rata-rata 3,73 dengan kriteria jawaban baik, hal ini dikarenakan karena karyawan wajib menjalankan prosedur perusahaan yang telah ditetapkan sesuai jabatannya masing-masing. 
Selanjutnya untuk dimensi etos kerja pada indikator tingkat ketelitian dalam bekerja memperoleh rata-rata 3,18 dengan kriteria cukup baik, hal tersebut disebabkan karena masih banyaknya temuan audit dan temuan accounting akibat ketidaktelitian karyawan dalam bekerja, banyak juga koreksi yang dilakukan akibat salah penginputan oleh karyawan. Pada indikator kemampuan dalam melakukan pekerjaan memperoleh nilai ratarata 3,83 dengan kriteria baik, hal tersebut disebabkan karena karyawan telah diberikan pelatihan guna meningkatkan kemampuan dalam bekerja. Pada indikator yang terakhir yaitu tingkat kepatuhan terhadap peraturan memperoleh nilai rata-rata 3,63 dengan kriteria baik, hal ini dikarenakan karyawan wajib mematuhi segala bentuk peraturan dan ketentuan yang telah ditetapkan perusahaan.

Selanjutnya untuk dimensi keterampilan pada indikator penguasaan terhadap ilmu pengetahuan dengan nilai rata-rata 3,75 dengan kriteria baik, hal tersebut dikarenakan atasan selalu memberikan informasi perbankan yang dapat meningkatkan ilmu pengetahuan. Pada indikator penguasaan terhadap teknologi memperoleh nilai rata-rata sebesar 3,73 dengan kriteria baik, hal ini dikarenakan karyawan diberikan pelatihan dalam menggunakan teknologi seperti komputer, berupa cara penginputan. Pada indikator yang terakhir yaitu tingkat keunggulan dalam bekerja nilai rata-rata 3,83 dengan kriteria baik, karena karyawan menguasai pekerjaannya dan rata-rata karyawan mendapat nilai yang baik.

Selanjutnya untuk dimensi terakhir pendidikan pada indikator sosialisasi yang diberikan atasan memperoleh nilai rata-rata 3,75 dengan kriteria jawaban baik, hal disebabkan karena atasan selalu memberikan masukan dan arahan dalam memecahkan masalah maupun dalam menyelesaikan pekerjaan. Pada indikator pelatihan yang diberikan dalam meningkatkan kemampuan dengan nilai rata-rata 3,75 dengan kriteria baik, hal tersebut disebabkan karena selalu diadakan pelatihan pada masing-masing bagian yang berguna untuk meningkatkan pengetahuan dan kemampuan karyawan agar bekerja lebih baik lagi. Pada indikator yang terakhir yaitu pengembangan karir pada PT Bank Mestika Dharma, Tbk. Cabang Pematangsiantar memperoleh nilai rata-rata 3,80 dengan kriteria baik, hal dikarenakan adanya pengangkatan jabatan kepada karyawan yang berprestasi dan rajin bekerja.

Dari total jawaban responden mengenai produktivitas kerja karyawan dari segi dimensi motivasi, kedisiplinan, etos kerja, keterampilan dan pendidikan memperoleh nilai rata-rata 3,74 dengan kriteria jawaban baik. Nilai rata-rata tertinggi sebesar 4,10 dengan kriteria baik untuk dimensi motivasi pada indikator pemahaman atas terhadap kemampuan karyawan. Sedangkan nilai terendah sebesar 3,18 dengan kriteria cukup baik untuk dimensi etos kerja pada indikator tingkat ketelitian dalam bekerja.

\section{b. Deskriptif Kuantitatif}

\section{1) Regresi Linear Berganda}

Analisa regresi linier berganda digunakan untuk mengetahui pengaruh variabel bebas $(X)$ dan variabel terikat $(Y)$, dimana $X$ adalah budaya organisasi, disiplin kerja dan $\mathrm{Y}$ adalah produktivitas kerja karyawan. Maka dilakukan perhitungan mengunakan program aplikasi SPSS untuk memperoleh nilai $a$ dan $b$ dengan notasi sebagai berikut: $\ddot{Y}=a+b_{1} X_{1}+b_{2} X_{2}$. Hasil regresi berganda dapat dilihat pada tabel berikut ini:

Tabel 3

Hasil Regresi Linier Berganda Coefficients $^{\mathrm{a}}$

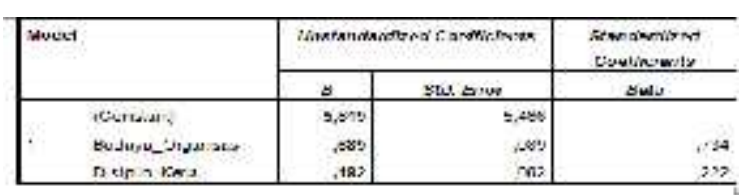

a. Dependent Variabel: Produktivitas Kerja Sumber: hasil pengolahan data dengan SPSS versi 20

Berdasarkan hasil pengolahan data pada tabel 3 diperoleh model persamaan $\hat{Y}=5,819+$ $0,689 X_{1}+0,192 X_{2}$, artinya terdapat pengaruh yang positif antara budaya organisasi $\left(X_{1}\right)$ dan disiplin kerja $\left(X_{2}\right)$ terhadap produktivitas kerja karyawan (Y) pada PT Bank Mestika Dharma, Tbk. Cabang Pematangsiantar.

\section{2) Koefisien Korelasi dan Koefisien \\ Determinasi}

Selanjutnya, dilakukan perhitungan korelasi berupa derajat atau kedalaman hubungan fungsional yang menjelaskan hubungan antar perubah, dinyatakan dengan yang dinamakan koefisien korelasi yang sering disimbolkan dengan R. Berikut tabel hasil koefisien korelasi dan determinasi:

Tabel 4

Hasil Koefisien Korelasi dan Determinasi Model Summary

\begin{tabular}{|c|c|c|c|c|}
\hline Moodit & R & R Square & Aquus led R Square & Stdi Error of th $\theta$ Esthlas \\
\hline+ & $344^{\circ}$ & .913 & $.65:$ & $3,4=5$ \\
\hline
\end{tabular}

a. Predictors: (Constant), Disiplin Kerja,

Budaya Organisasi

b. Dependent Variabel: Produktivitas Kerja

Sumber: hasil pengolahan data dengan SPSS versi 20

Dari hasil koefisien korelasi pada tabel 4 di atas diperoleh nilai $r=0,844$, yang artinya terdapat hubungan yang sangat kuat dan positif antara budaya organisasi dan disiplin kerja dengan produktivitas kerja karyawan pada PT Bank Mestika Dharma, Tbk. Cabang Pematangsiantar. Kemudian diperoleh nilai 
koefisien determinasi ( $R$ Square $)=0,713$, artinya tinggi rendahnya produktivitas kerja karyawan (Y) pada PT Bank Mestika Dharma, Tbk Cabang Pematangsiantar sebesar $71,3 \%$ dapat dijelaskan oleh budaya organisasi $\left(X_{1}\right)$ dan disiplin kerja $\left(\mathrm{X}_{2}\right)$, sedangkan sisanya sebesar $28,7 \%$ dipengaruhi oleh faktor lain seperti kompensasi, pelatihan, lingkungan kerja dan lain-lain yang tidak dibahas dalam penelitian ini.

\section{3) Uji Hipotesis}

a) Uji Simultan (Uji F)

Pengujian ini dilakukan secara simultan, yaitu dilakukan untuk menentukan diterima atau ditolaknya hipotesis. Pengujian hipotesis dilakukan untuk mengetahui apakah variabel kualitas produk dan harga yang diuji berpengaruh terhadap Kepuasan Konsumen. Jika $F_{\text {hitung }}>F_{\text {tabel }}$ atau signifikansi $\leq 0,05$, maka $\mathrm{H}_{0}$ ditolak.

Untuk menghasilkan suatu kesimpulan yang valid, maka harus dilakukan uji hipotesis. Dari hasil perhitungan koefisien korelasi diketahui bahwa budaya organisasi, disiplin kerja dan produktivitas kerja karyawan sangat berhubungan. Berikut ini tabel perkiraan nilai $F_{\text {hitung: }}$

Tabel 5

Hasil Uji Simultan (Uji F)

ANOVA

\begin{tabular}{|c|c|c|c|c|c|c|}
\hline sto & & $\begin{array}{l}\text { Sckn of } \\
\text { 5quarcs }\end{array}$ & $D r$ & Heso Square & $F$ & Sig. \\
\hline & $-x y$ ceston & 280861 & 2 & 293,290 & 43.434 & 803 \\
\hline 1 & $\begin{array}{l}\text { Tcsijual } \\
\text { Jla }\end{array}$ & 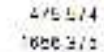 & $\begin{array}{l}3 t \\
33\end{array}$ & $2,3,33$ & & \\
\hline
\end{tabular}

a. Dependent Variabel: Produktivitas Kerja

b. Predictors: (Constant), Disiplin Kerja,

Budaya Organisasi

Sumber: hasil pengolahan data dengan SPSS versi 20

Berdasarkan tabel 5 di atas diperoleh nilai $F_{\text {hitung }}$ sebesar $45,934>F_{\text {tabel }}$ dengan $(0,05 ; 2$ vs 37) sebesar 3,25 atau dengan signifikan $0,000<\alpha 0,05$, maka $\mathrm{H}_{0}$ ditolak, artinya budaya organisasi dan disiplin kerja berpengaruh positif dan signifikan terhadap produktivitas kerja karyawan PT Bank Mestika Dharma, Tbk. Cabang Pematangsiantar.

\section{b) Uji Parsial (Uji t)}

Pengujian ini dilakukan secara parsial yaitu dilakukan untuk menentukan diterima atau ditolaknya hipotesis, pengujian hipotesis dilakukan untuk mengetahui apakah variabel budaya organisasi dan disiplin kerja yang diuji berpengaruh terhadap produktivitas kerja karyawan. Jika $t_{\text {hitung }}>t_{\text {tabel }}$ atau tingkat signifikansi $\leq \alpha \quad 0,05$ maka $\mathrm{H}_{0}$ ditolak. Adapun pengujian positif (uji t) dapat dilihat sebagai berikut:
Tabel 6

Perkiraan Nilai $t_{\text {hitung }}$ Coefficients $^{\mathrm{a}}$

\begin{tabular}{|c|c|c|c|}
\hline Mod: & & 1 & 54 \\
\hline & Songenal: & 1,30 & $\therefore 34$ \\
\hline 1 & ZdJaya_Jrgarleas & 7,700 & ,000 \\
\hline & 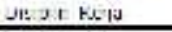 & 2,331 & 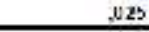 \\
\hline
\end{tabular}

a. Dependent Variabel: Produktivitas Kerja

Sumber: hasil pengolahan data dengan SPSS versi 20

Berdasarkan tabel 6 di atas diperoleh nilai $t_{\text {hitung }}$ pada variabel $\mathrm{X}_{1}$ (budaya organisasi) sebesar $7,708>$ dari $t_{\text {tabel }}$ dengan $\mathrm{df}=\mathrm{n}-\mathrm{k}-1$ (40$2-1=37$ ) sebesar 2,026 atau taraf signifikan $0,000<\alpha 0,05$, maka $\mathrm{H}_{0}$ ditolak, artinya budaya organisasi berpengaruh positif dan signifikan terhadap produktivitas kerja karyawan PT Bank Mestika Dharma, Tbk. Cabang Pematangsiantar. Kemudian nilai $t_{\text {hitung }}$ pada variabel $\mathrm{X}_{2}$ (disiplin kerja) sebesar 2,331 > dari $t_{\text {tabel }}$ dengan $\mathrm{df}=\mathrm{n}-\mathrm{k}-1,(40-2-1=37)$ sebesar 2,026 atau taraf signifikan $0,025<\alpha 0,05$, maka $\mathrm{H}_{0}$ ditolak, artinya disiplin kerja berpengaruh positif dan signifikan terhadap produktivitas kerja PT Bank Mestika Dharma, Tbk. Cabang Pematangsiantar.

\section{Evaluasi}

a. Budaya Organisasi Pada PT Bank Mestika Dharma, Tbk. Cabang Pematangsiantar

Berdasarkan hasil kuisioner yang dibagikan kepada responden mendapat nilai rata-rata keseluruhan sebesar 3,83 dalam kriteria jawaban baik. Namun ada beberapa aspek walaupun dinilai baik tetapi masih ada yang dinilai dibawah rata-rata dari indikatorindikator lain.

Dimensi pertama yang memperoleh nilai terendah 3,13 terdapat pada dimensi komitmen pada indikator keinginan karyawan dalam mewujudkan tujuan perusahaan. Penyebabnya adalah karyawan tidak bekerja dengan sepenuh hati dan kurang maksimal sehingga rendahnya keinginan karyawan dalam mewujudkan tujuan perusahaan. Cara mengatasinya dengan memberikan motivasi kepada karyawan agar bekerja dengan maksimal dikarenakan kesejahteraan karyawan merupakan bagian dari tujuan perusahaan. Apabila tujuan perusahaan tercapai, perusahaan dan karyawan samasama memperoleh keuntungan.

Pada dimensi kompetensi pada indikator tanggung jawab terhadap pekerjaan memperoleh nilai dibawah rata-rata sebesar 3,75 dikarenakan masih adanya karyawan yang lalai dalam bekerja. Hal ini dapat diatasi dengan memberikan sosialisasi kepada karyawan akan sanksi yang diberikan apabila melakukan kesalahan. Pada dimensi keterbukaaan pada indikator kepercayaan antar karyawan memperoleh nilai dibawah rata-rata sebesar 3,63 Hal ini dikarenakan adanya karyawan yang salah dalam penyampaian informasi sehingga 
timbul kesalahpahaman antar karyawan. Cara mengatasi yaitu dengan memastikan dahulu informasi yang akan disampaikan sudah benar dan relevan.

Pada indikator hubungan antar karyawan memperoleh nilai 3,75 disebabkan karena kurangnya komunikasi yang baik antar sesama karyawan. Cara mengatasinya yaitu dengan memberikan informasi terbaru melalui media seperti majalah dinding dan email kepada sesama karyawan. Indikator yang terakhir yaitu keterbukaan informasi dengan karyawan lain memperoleh nilai 3,73 dikarenakan adanya karyawan yang tidak mengetahui perkembangan perusahaan sehingga karyawan merasa ada yang ditutupi oleh perusahaan. Cara mengatasi yaitu dengan terbuka kepada karyawan, maka karyawan akan merasa nyaman dan dapat bekerja maksimal untuk perusahaan.

Pada dimensi kejujuran pada indikator kerelevan informasi yang diberikan dibawah rata-rata sebesar 3,70. Hal ini disebabkan karena adanya karyawan yang salah dalam penyampaian informasi sehingga timbul kesalahpahaman antar karyawan. Cara mengatasi yaitu dengan memastikan dahulu informasi yang akan disampaikan sudah benar dan relevan. Indikator terakhir yaitu kejujuran sesama karyawan memperoleh nilai 3,75 disebabkan karena adanya karyawan yang tidak mengakui kesalahan yang ia lakukan. Cara mengatasinya yaitu dengan memberikan kritik dan saran kepada karyawan untuk memperbaiki kesalahannya dan tidak mengulanginya lagi.

Dari evaluasi budaya organisasi di atas dapat diambil kesimpulan bahwa semua hal-hal di atas sudah berada pada nilai dengan kriteria jawaban kuat. Sebenarnya perusahaan sudah cukup kuat dalam menerapkan budaya organisasi di lingkungan kerja. Namun apabila beberapa hal di atas dapat diatasi dan ditingkatkan lagi, tentunya akan memberikan manfaat yang lebih baik bagi perusahaan.

\section{b. Disiplin Kerja Pada PT Bank Mestika Dharma, Tbk. Cabang Pematangsiantar}

Berdasarkan hasil kuesioner yang dibagikan kepada responden diperoleh nilai rata-rata sebesar 3,90 dengan kriteria jawaban baik, namun ada beberapa aspek yang walaupun dinilai baik tetapi nilainya masih dibawah rata-rata dari indikator-indikator lain.

Dimensi pertama paling rendah adalah dimensi tingkat kehadiran pada indikator ketepatan waktu datang bekerja memperoleh nilai 3,40 . Penyebabnya adalah banyaknya absensi keterlambatan karyawan. Cara mengatasinya adalah dengan memberikan sanksi keterlambatan bagi karyawan yang datang terlambat. Pada indikator selanjutnya memperoleh nilai dibawah rata-rata sebesar
3,80 dengan indikator tingkat kehadiran di tempat kerja. Disebabkan oleh beberapa karyawan yang tidak hadir akibat sakit ringan yang sebenarnya masih bisa diatasi. Hal ini dapat diatasi dengan cara memastikan bahwa karyawan tersebut benar-benar sakit melalui surat dokter.

Selanjutnya pada dimensi ketaatan pada Standart Operation Procedure pada indikator kebersihan lingkungan kerja memperoleh nilai 3,75 . Hal ini disebabkan masih terdapatnya debu pada meja kerja maupun lantai yang kotor. Cara mengatasinya dengan cara memberikan sosialisasi kepada petugas kebersihan agar benar-benar membersihkan meja maupun lantai dengan bersih, dan juga kesadaran masing-masing karyawan untuk sama-sama menjaga kebersihan lingkungan kerja. Indikator selanjutnya yaitu efisiensi penggunaan fasilitas kantor memperoleh nilai dibawah rata-rata yaitu 3,60 . Hal ini disebabkan masih adanya beberapa karyawan menggunakan fasilitas kantor secara tidak efektif seperti menggunakan mesin fotocopy untuk keperluan pribadi. Hal ini dapat diatasi dengan memberikan sosialisasi penghematan penggunaan fasilitas kantor agar biaya operasional perusahaan dapat diminimalisasi. Indikator yang terakhir yaitu ketaatan terhadap peraturan memperoleh nilai 3,70 dikarenakan adanya karyawan yang tidak taat pada peraturan misalnya memakai sandal pada saat jam kerja, tidak memakai name tag. Hal ini dapat diatasi dengan memberikan sanksi kepada karyawan yang tidak taat terhadap peraturan

Dalam hal ini jawaban dari responden sudah pada kriteria jawaban baik. Namun perusahaan harus lebih meningkatkan lagi disiplin kerja agar memperoleh nilai sangat baik dengan cara memberikan sanksi kepada karyawan yang tidak disiplin sehingga karyawan menaati peraturan perusahaan.

\section{c. Produktivitas Kerja Pada PT Bank Mestika Dharma, Tbk. Cabang Pematangsiantar}

Indikator Produktivitas Kerja Karyawan PT Bank Mestika Dharma, Tbk. Cabang Pematangsiantar sudah dikatakan baik. Hal ini dapat dilihat dari jawaban responden dengan nilai keseluruhan rata-rata di 3,74 dengan kriteria jawaban baik.

Namun tentunya ada beberapa indikator yang perlu diperhatikan karena nilainya masih dibawah rata-rata. Nilai paling rendah pertama yaitu untuk dimensi etos kerja pada indikator tingkat ketelitian dalam bekerja dengan nilai dibawah rata-rata 3,18. Hal disebabkan karena masih banyaknya temuan audit dan temuan accounting akibat ketidaktelitian karyawan dalam bekerja, banyak juga koreksi yang dilakukan akibat salah penginputan oleh 
karyawan. Hal ini dapat diatasi dengan memberikan sanksi berupa surat peringatan kepada karyawan yang melakukan kesalahan yang fatal seperti salah penginputan yang baru diketahui keesokan harinya. Kemudian pada indikator tingkat kepatuhan terhadap peraturan memperoleh nilai 3,63 dikarenakan adanya karyawan yang melanggar peraturan perbankan. Cara mengatasinya yaitu dengan memberikan sanksi berupa teguran, baik secara lisan maupun tulisan kepada karyawan yang melanggar peraturan perbankan.

Kemudian dimensi motivasi yaitu pada indikator dukungan yang diberikan atasan mendapat nilai dibawah rata-rata 3,73 . Hal ini disebabkan kurangnya dukungan yang diberikan atasan terhadap karyawan dalam menyelesaikan pekerjaan. Cara mengatasinya yaitu memberikan dukungan dan saran kepada karyawan yang kesusahan dalam menyelesaikan pekerjaan.

Pada dimensi selanjutnya yaitu kedisiplinan pada indikator tingkat kehadiran memperoleh nilai dibawah rata-rata sebesar 3,73 . Hal ini dikarenakan beberapa karyawan yang tidak hadir akibat sakit ringan yang sebenarnya masih bisa diatasi. Hal ini dapat diatasi dengan cara memastikan bahwa karyawan tersebut benar-benar sakit melalui surat dokter. Selanjutnya pada indikator ketaatan terhadap prosedur kerja memperoleh nilai dibawah rata-rata sebesar 3,73 . Hal ini dikarenakan beberapa karyawan yang memakai sandal saat bekerja. Hal ini dapat diatasi dengan memberikan teguran langsung kepada karyawan tersebut.

Dari evaluasi produktivitas kerja karyawan di atas dapat diambil kesimpulan bahwa semua hal-hal di atas sudah berada pada nilai dengan kriteria jawaban baik. Sebenarnya perusahaan sudah cukup benar dalam hal meningkatkan produktivitas kerja karyawan, namun apabila beberapa hal di atas dapat di atasi dan ditingkatkan lagi, maka perusahaan dapat mencapai produktivitas kerja yang tinggi. Untuk meningkatkan produktivitas kerja yang tinggi, pimpinan dan atasan PT Bank Mestika Dharma, Tbk. Cabang Pematangsiantar dapat memberikan motivasi, dukungan, serta senantiasa mendorong karyawannya untuk melakukan upaya-upaya yang maksimal dalam mengerjakan pekerjaannya dengan teliti dan meminimalisasi kesalahan untuk mencapai tujuan perusahaan.

\section{KESIMPULAN DAN SARAN}

\section{Kesimpulan}

a. Dari hasil analisis deskriptif kualitatif tentang budaya organisasi baik dari segi komitmen, kompetensi, kerjasama, keterbukaan dan kejujuran mendapat nilai rata-rata sebesar 3,83 dengan kriteria jawaban kuat. Kemudian nilai rata-rata tertinggi sebesar
4,30 dengan kriteria jawaban sangat kuat untuk dimensi kerjasama pada indikator kerjasama yang solid di dalam tim. Sedangkan nilai rata-rata terendah sebesar 3,13 untuk dimensi komitmen pada indikator keinginan karyawan dalam mewujudkan tujuan perusahaan.

b. Dari hasil analisis deskriptif kualitatif tentang disiplin kerja baik dari segi tingkat kehadiran, ketaatan pada Standart Operation Procedure, ketaatan pada kode etik, dan pelaksanaan Good Corporate Governance mendapat nilai rata-rata sebesar 3,90 dengan kriteria jawaban baik. Kemudian nilai rata-rata tertinggi sebesar 4,15 dengan kriteria jawaban baik untuk dimensi ketaatan pada kode etik pada indikator perlindungan terhadap aset-aset bank dan pada dimensi pelaksanaan Good Corporate Governance pada indikator tingkat kepuasan hasil kerja. Sedangkan nilai rata-rata terendah sebesar 3,40 dengan kriteria jawaban cukup baik untuk dimensi tingkat kehadiran pada indikator ketepatan waktu datang bekerja.

c. Dari hasil analisis deskriptif kualitatif tentang produktivitas kerja karyawan dari segi dimensi motivasi, kedisiplinan, etos kerja, keterampilan, dan pendidikan memperoleh nilai rata-rata 3,74 dengan kriteria jawaban baik. Nilai rata-rata tertinggi sebesar 4,10 dengan kriteria jawaban baik untuk dimensi motivasi pada indikator pemahaman atasan terhadap kemampuan karyawan. Sedangkan nilai terendah sebesar 3,18 dengan kriteria jawaban cukup baik untuk dimensi etos kerja pada indikator tingkat ketelitian dalam bekerja.

d. Hasil analisis regresi linear berganda yang dihitung melalui program SPSS versi 20 diperoleh model persamaan $\hat{Y}=5,819+$ $0,689 X_{1}+0,192 X_{2}$ artinya terdapat pengaruh yang positif antara budaya organisasi $\left(X_{1}\right)$ dan disiplin kerja $\left(\mathrm{X}_{2}\right)$ terhadap produktivitas kerja karyawan ( $\mathrm{Y}$ ) pada PT Bank Mestika Dharma, Tbk. Cabang Pematangsiantar.

e. Hasil analisis korelasi diperoleh nilai $r$ sebesar 0,844 , yang artinya terdapat hubungan yang sangat kuat dan positif antara budaya organisasi, disiplin kerja, dan produktivitas kerja karyawan pada PT Bank Mestika Dharma, Tbk. Cabang Pematangsiantar. Kemudian diperoleh nilai koefisien determinasi $(R$ Square $)=0,713$, artinya tinggi rendahnya produktivitas kerja karyawan (Y) pada PT Bank Mestika Dharma, Tbk Cabang Pematangsiantar sebesar $71,3 \%$ dapat dijelaskan oleh budaya organisasi $\left(X_{1}\right)$ dan disiplin kerja $\left(X_{2}\right)$, sedangkan sisanya sebesar $28,7 \%$ dipengaruhi oleh faktor lain, seperti kompensasi, pelatihan, lingkungan kerja dan lain-lain yang tidak dibahas dalam penelitian ini. 
f. Melalui pengujian hipotesis dengan uji $F$ (uji simultan), terdapat pengaruh yang positif dan signifikan antara budaya organisasi dan disiplin kerja terhadap produktivitas kerja karyawan, nilai $F_{\text {hitung }}$ sebesar 45,934 $>F_{\text {tabel }}$ dengan $(0,05 ; 2$ vs 37$)$ sebesar 3,25 , dengan taraf signifikan $0,000<\alpha 0,05$, maka $\mathrm{H}_{0}$ ditolak, artinya budaya organisasi dan disiplin kerja berpengaruh positif dan signifikan terhadap produktivitas kerja karyawan PT Bank Mestika Dharma, Tbk Cabang Pematangsiantar secara simultan.

g. Melalui pengujian hipotesis dengan uji t (uji parsial), diperoleh nilai $t_{\text {hitung }}$ pada variabel $X_{1}$ (budaya organisasi) sebesar $7,708>$ dari $t_{\text {tabel }}$ dengan $d f=n-k-1(40-2-1=37)$ sebesar 2,026 atau taraf signifikan $0,000<\alpha 0,05$, maka $\mathrm{H}_{0}$ ditolak, artinya budaya organisasi berpengaruh positif dan signifikan terhadap produktivitas kerja karyawan pada kantor PT Bank Mestika Dharma, Tbk. Cabang Pematangsiantar. Kemudian nilai $t_{\text {hitung }}$ pada variabel $\mathrm{X}_{2}$ (disiplin kerja) sebesar 2,331 atau taraf signifikan $0,025<\alpha$ 0,05, maka $\mathrm{H}_{0}$ ditolak, artinya disiplin kerja berpengaruh positif dan signifikan terhadap produktivitas kerja PT Bank Mestika Dharma, Tbk. Cabang Pematangsiantar.

\section{Saran}

a. Hendaknya PT Bank Mestika Dharma, Tbk. Cabang Pematangsiantar lebih memperhatikan penerapan budaya organisasi yang ada pada lingkungan perusahaan, akan lebih baik apabila pimpinan dapat mengarahkan dan mengingatkan karyawan tentang pentingnya penerapan budaya organisasi di tempat kerja agar tujuan perusahaan dapat tercapai.

b. Sebaiknya pimpinan PT Bank Mestika Dharma, Tbk. Cabang Pematangsiantar memperhatikan dan memberikan arahan kepada seluruh karyawan serta memberikan sanksi kepada karyawan yang tidak disiplin, terutama kepada karyawan yang hadir tidak tepat waktu.

c. Untuk meningkatkan produktivitas kerja karyawan, pimpinan dan atasan PT Bank
Mestika Dharma, Tbk. Cabang Pematangsiantar dapat memberikan motivasi, dukungan, serta senantiasa mendorong karyawannya untuk melakukan upaya-upaya yang maksimal dalam mengerjakan pekerjaannya dengan teliti dan meminimalisasi kesalahan untuk mencapai tujuan perusahaan.

\section{E. DAFTAR PUSTAKA}

Bank Mestika Dharma, 2015.

http://bankmestika.co.id/index. php? operation=reports. Diakses tahun 2016.

Bank Mestika Dharma, 2015. Surat Keputusan. No.19/SK-BMD/DIR/ 2015 Disiplin Kerja Karyawan PT Bank Mestika Dharma, Tbk Cabang Pematangsiantar.

Dessler, Gary. 2004. Manajemen Sumber Daya Manusia. Jakarta: Prenhallindo.

Bestari, Mitra. 2004. Manajemen Operasi. Edisi 1. Yogyakarta: Unit Penerbitan Fakultas Ekonomi (UPFE-UMY).

Mathis, Robert L. dan John H. Jackson. 2006. Human Resources Management. Edisi 10. Jakarta: Salemba Empat.

Robbins, Stephen P. dan Thimothy A. Judge. 2008. Perilaku Organisasi. Edisi 12. Jakarta: Salemba Empat.

Serdamayanti. 2011. Tata Kerja dan Produktivitas Kerja. Bandung: Mandar Maju.

Sinungan, Muchdarsyah. 2009. Produktivitas. Jakarta: Bumi Aksara.

Sirait, T. Justin. 2006. Memahami Aspekaspek Pengelolaan Sumber Daya Manusia dalam Organisasi. Jakarta: Gramedia Widiasarana Indonesia.

Sutrisno, Edy. 2009. Manajemen Sumber Daya Manusia. Cetakan 1. Jakarta: Kencana Prenada Media Group.

, 2010. Budaya Organisasi. Cetakan 1, Edisi 1. Jakarta: Kencana Prenada Media Group. 